\title{
ENHANCING BANANA (Musa spp.) GROWTH AND PRODUCTIVITY BY BIO-FERTILIZERS IN SANDY SOIL
}

\author{
El-Morshedy, F. - AyAAD, H. - ABOU ElyAZID, D. M.* - OMER, M. K. \\ Horticulture Department, Faculty of Agriculture, Kafrelsheikh University \\ 33516 Kafr El-Sheikh, Egypt \\ ${ }^{*}$ Corresponding author \\ e-mail:delgiar@agr.kfs.edu.eg \\ (Received $10^{\text {th }}$ May 2020; accepted $13^{\text {th }}$ Aug 2020)
}

\begin{abstract}
This investigation was carried out during the two successive seasons of 2016 and 2017 at the private orchard of the modern agriculture company (PICO), El Behera governorate, Egypt, to study the effect of Nitrogen Fixing Bacteria (NFB) and Phosphate Solubilizing Bacteria (PSB) and different rates of $\mathrm{N}$ and $\mathrm{P}$ as mineral fertilizers (i.e. 50\% and $75 \%$ of recommended dose), compared to the standard recommended mineral fertilization on the growth, yield, fruit quality and leaf mineral contents of Williams banana plants. Results showed that $\mathrm{T}_{8}(50 \%$ bio $\mathrm{N}+50 \%$ bio. $\mathrm{P}+50 \%$ mineral $\mathrm{N}$ and $\mathrm{P})$ and $\mathrm{T}_{7}$ (100\% bio $\mathrm{N}+50 \%$ bio. $\mathrm{P}+50 \%$ mineral $\mathrm{N}$ and $\mathrm{P}$ ) enhanced plant growth i.e. pseudostem length and perimeter also, it increased bunch weight and yield and improved most physical parameters (i.e. finger no./hand, finger length, finger weight, pulp weight, pulp weight and pulp ratio) and chemical characters (T.S.S, total sugar $\%$ and reducing sugar $\%$ ), leaf mineral content (N, P, and $\mathrm{K}$ ) and chlorophyll a and b were also significantly affected by treatments compared to the control during two season of study. The results suggest that, the utilized biofertilizers can partially substitute the amount of mineral fertilizers, leading to cleaner environment.
\end{abstract}

Keywords: $P$ dissolving bacteria, $N$ fixing bacteria, fruit quality, yield, Williams, sustainable agriculture

\section{Introduction}

Banana (Musa sp.) is a major crop in tropical and subtropical regions of the world. In Egypt, it represents most important fruit crop after citrus and grapes. It coveres an area of 28667 hectares with production of 1228458 tons in 2017 (FAO STAT). Among Crop management practices, plant nutrition in particular represents one of the major factors influencing banana yield. Moreover, all soils are deficient in N, P and K (Akhtar et al., 2003), besides, soil organic matter contents are low (Abbas et al., 2012) and this is true in new reclaimed lands in Egypt. Fertilization is very important not only to meet the crop requirements but also to improve soil fertility.

Soil microorganisms have enormous role in increasing the availability of accumulated phosphates in the soil for plant by solubilization (Goldstien, 1986; Gyaneshwar et al., 2002; Hamim et al., 2019). Moreover, the microorganisms involved $\mathrm{P}$ solubilization as well as better scavenging of soluble $\mathrm{P}$ can enhance plant growth by increasing the efficiency of biological nitrogen fixation, enhancing the availability of other trace elements and by production of plant growth promoting substances (Goldstien, 1986). This assumes more important for banana, which is a heavy feeder crop requiring large amount of nutrients (Ganapathi and Dharmatti, 2018).

Williams is one of the most widely grown banana varieties in the world (Xu et al., 2005; FAO, 2018). In Egypt, it is cultivated successfully in newly reclaimed soils for its excellent performance, the large bunch with longer fingers, the excellent taste and high tolerance to transportation (Barakat et al., 2011). Very little information is available on the effect of biofertilizers (Azotobacter chroococcum and Bacillus megatherium var 
phospahaticum) on this variety under sandy soil condition. Thus, the present investigation was undertaken to study the effect of biofertilizers as ecofriendly, and low-cost alternative fertilizers on growth and yield attributes of Williams banana.

\section{Materials and methods}

The present investigation was conducted during two successive seasons (2016 and 2017 ) in a private orchard of the modern agriculture company (PICO) located at Badr city $\left(30^{\circ} 36^{\prime} 36.5^{\prime \prime} \mathrm{N}\right.$ and $\left.30^{\circ} 45^{\prime} 45.5^{\prime \prime} \mathrm{E}\right)$, El Behera governorate, Egypt (Fig. 1). Monthly average of some metrological data during study period of the experimental site is illustrated in Figure 2.

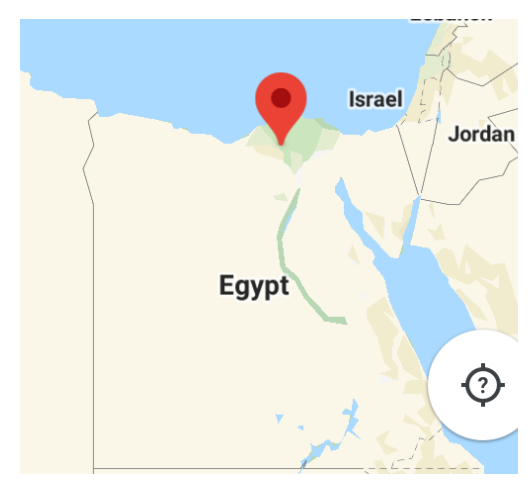

Figure 1. Experimental site location

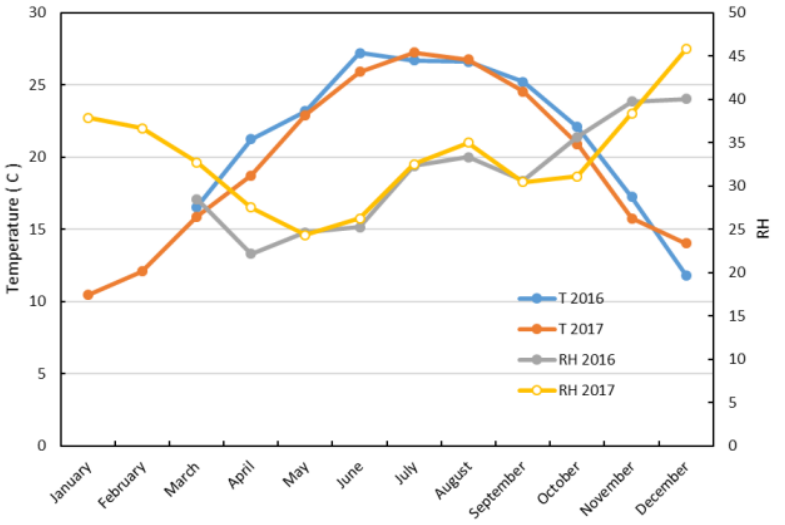

Figure 2. Metrological data during study period of the experimental site

At the beginning of the treatments, three soil samples were collected from different sites at $90 \mathrm{~cm}$ depth and analyzed as a composite sample for physical and chemical properties according to (Wilde et al., 1985). The analysis of orchard soil is presented in Table 1 .

Table 1. Physical and chemical analysis of soil

\begin{tabular}{|c|c|c|c|c|c|c|c|}
\hline \multicolumn{8}{|c|}{ Chemical properties } \\
\hline pH & $\begin{array}{c}\text { E.C } \\
(\mathrm{mmhos} / \mathrm{cm})\end{array}$ & $\begin{array}{c}\text { Organic } \\
\text { matter \% }\end{array}$ & $\begin{array}{c}\text { Organic } \\
\text { carbon \% }\end{array}$ & $\begin{array}{c}\text { P(available }) \\
\text { Meq/L }\end{array}$ & SAR & $\begin{array}{c}\mathrm{K} \\
\mathrm{mg} / 100 \mathrm{~g}\end{array}$ & $\begin{array}{c}\mathrm{Ca} \\
\mathrm{Meq} / \mathrm{L}\end{array}$ \\
\hline 8.3 & 0.18 & 0.68 & 0.39 & 24 & 0.52 & 0.15 & 0.8 \\
\hline \multicolumn{8}{|c|}{ Physical properties } \\
\hline \multicolumn{2}{|c|}{ Sand $(\%)$} & \multicolumn{2}{|c|}{ Loam (\%) } & \multicolumn{2}{|c|}{ Clay (\%) } & \multicolumn{2}{|c|}{ Density (g/cm3) } \\
\hline \multicolumn{2}{|r|}{75} & \multicolumn{2}{|c|}{8.75} & \multicolumn{2}{|c|}{16.25} & \multicolumn{2}{|c|}{1.21} \\
\hline
\end{tabular}

The mother plants were planted in mid-March at $3.5^{*} 1.5 \mathrm{~m}$ apart, received $30 \mathrm{~m}^{3}$ organic matter/Feddan/year. Eight treatments were used; Control treatment fertilized by recommended dose of mineral fertilizers $\left(250,80\right.$ and 480 unite of NPK $/ 4200 \mathrm{~m}^{2} /$ year) in forms of ammonium nitrate $(33.5 \% \mathrm{~N})$, phosphoric acid $\left(80 \% \mathrm{P}_{2} \mathrm{O}_{5}\right)$ and potassium sulfate $\left(48 \% \mathrm{~K}_{2} \mathrm{O}\right)$, respectively. Two levels of each $\mathrm{N}$ and $\mathrm{P}(100 \%$ and $50 \%$ of recommended dose) were used in combination with two biofertilizers namely; 
Azotobacter chroococcum (Az14) as nonsymbiotic nitrogen fixation bactria (N.F.B) and Bacillus megatherium var phospahaticum (B6) as phosphate dissolving bacteria (P.D.B). The strains were obtained from Bacteriology Lab, Sakha. Agric. Res. Station. Three $\mathrm{kg} / 4200 \mathrm{~m}^{2}$ from each inoculum was used after mixed with suitable amount of sandy soil and added once at first week of April of each season in crescentic trenches around each plant. The chemical fertilizers were added through drip irrigation system from April to October. The recommended dose of $\mathrm{K}$ was applied to all treatments.

The applied treatments were as follows:

T1- Control (100\% mineral N, P fertilizers)

T2- $100 \%$ Bio P (P.D.B) $+100 \%$ mineral N

T3- $100 \%$ Bio $\mathrm{P}+50 \%$ mineral $\mathrm{P}+100 \%$ mineral $\mathrm{N}$

T4- $100 \%$ Bio N (N.F.B) + $100 \%$ mineral P

T5- $100 \%$ Bio $\mathrm{N}+50 \%$ mineral $\mathrm{N}+100 \%$ mineral $\mathrm{P}$

T6- $100 \%$ Bio $\mathrm{N}+100 \%$ Bio $\mathrm{P}$

T7 $-100 \%$ Bio $\mathrm{N}+100 \%$ Bio $\mathrm{P}+50 \%$ mineral $\mathrm{N}, \mathrm{P}$

T8- $50 \%$ Bio $\mathrm{P}+50 \%$ Bio N $+50 \%$ mineral $\mathrm{N}, \mathrm{P}$

\section{Vegetative growth measurements}

At the beginning of the florescence emergence the following parameters were recorded; Pseudostem length $(\mathrm{cm})$ which was measured from the soil surface up to the petiole of the last emerged leaf. Circumference of pseudostem $(\mathrm{cm})$ at $25 \mathrm{~cm}$ above soil surface.

\section{Yield and fruit quality}

In mid-February of each season, bunches were harvested at the green maturity stage. At harvest, bunch weight $(\mathrm{kg})$, bunch length $(\mathrm{cm})$, and finger number/hand were recorded, three hands were taken randomly/ bunch/ replicate to estimate fruit physical characters including finger weigh $(\mathrm{g})$, length and perimeter $(\mathrm{cm})$, pulp and peel weight / finger $(\mathrm{g})$ and pulp ratio. Fruit chemical characters were estimated in ripe fingers as total soluble solids in pulp juice (TSS) using hand refractometer as Brix, total titratable acidity percentage as malic acid was estimated using phenolphthalein as indicator according to (AOAC, 1985) and total and reducing sugars (Dubois et al., 1956).

\section{Leaf chlorophyll and mineral contents}

Leaf samples were taken from the middle part of third upper leaf blade. Chlorophyll ( $\mathrm{a}$ and $\mathrm{b}$ ) content expressed as $\mathrm{mg} / \mathrm{g}$ fresh weight was determined according to Moran and Porath (1980). Leaf samples were washed and oven dried at $70 \mathrm{c}$ to a constant weight. Total nitrogen was determined by using micro-kjedehl (AOAC, 1985). Potassium was measured using a flame-photometer and phosphorus was determined colorimetrically (Chapman and Pratt, 1961).

\section{Statistical analysis}

The obtained data in both seasons were statistically analyzed using analysis of variance method as simple experiment in randomized complete block design (Snedecor and Cochran, 1980) using CoStat 6.303, CoHort Software, 798 Lighthouse Ave. PMB 320, Monterey, CA, 93940, USA. Duncan' multiple range test were used for means comparison (Duncan, 1955). 


\section{Results and discussion}

\section{Growth characters}

Considering to height and circumference of pseudostem, data presented in Table 2 indicate that planta treated with $\mathrm{T}_{2}(100 \%$ Bio P (P.D.B $\left.)+100 \% \mathrm{~N}\right)$ recorded the lowest significant pseudostem length in the first season and so in the second season but with no significant difference with T3, T4 and T6. Whereas, the highest pseudostem length was recorded at $\mathrm{T}_{8}(50 \%$ Bio $\mathrm{P}+50 \%$ Bio $\mathrm{N}+50 \%$ mineral $\mathrm{NP})$, especially in the second season.

Table 2. Effect of Biofertilizers in combination with different levels of $N$, $P$ mineral fertilizers on vegetative growth characters

\begin{tabular}{c|c|c|c|c}
\hline \multirow{2}{*}{ Treatments } & \multicolumn{2}{|c|}{$\begin{array}{c}\text { Pseudostem } \\
\text { length }(\mathbf{c m})\end{array}$} & \multicolumn{2}{c}{$\begin{array}{c}\text { Pseudostem } \\
\text { Circumference (cm) }\end{array}$} \\
\cline { 2 - 5 } & $\mathbf{2 0 1 6}$ & $\mathbf{2 0 1 7}$ & $\mathbf{2 0 1 6}$ & $\mathbf{2 0 1 7}$ \\
\hline T1 & $200.0 \mathrm{a}$ & $194.8 \mathrm{~b}$ & $47.25 \mathrm{~b}$ & $49.5 \mathrm{bcd}$ \\
T3 & $172.5 \mathrm{c}$ & $187.5 \mathrm{~d}$ & $40.25 \mathrm{c}$ & $46.25 \mathrm{e}$ \\
T4 & $184.5 \mathrm{~b}$ & $189.5 \mathrm{~cd}$ & $49.0 \mathrm{~b}$ & $48.5 \mathrm{cde}$ \\
T5 & $188.3 \mathrm{ab}$ & $191.3 \mathrm{bcd}$ & $45.75 \mathrm{~b}$ & $47.25 \mathrm{de}$ \\
T6 & $199.3 \mathrm{a}$ & $193.0 \mathrm{bc}$ & $49.5 \mathrm{~b}$ & $49.5 \mathrm{bcd}$ \\
T7 & $195.0 \mathrm{ab}$ & $189.5 \mathrm{~cd}$ & $49.25 \mathrm{~b}$ & $50.25 \mathrm{abcd}$ \\
T8 & $197.0 \mathrm{ab}$ & $193.8 \mathrm{~b}$ & $53.5 \mathrm{a}$ & $50.5 \mathrm{abc}$ \\
\hline
\end{tabular}

Means within each column followed by the same letter are not significantly different at $\mathrm{P} \leq 0.05$ according to Duncan's multiple range test. T1: Control (100\% mineral NP), T2: $100 \%$ Bio P (P.D.B) $+100 \%$ N, T3: $100 \%$ Bio P + 50\% mineral P $+100 \%$ N, T4: $100 \%$ Bio N (N.F.B) $+100 \%$ mineral P, T5: $100 \%$ Bio N + 50\% mineral N +100\% mineral P, T6: $100 \%$ Bio N +100\% Bio P, T7: $100 \%$ Bio N $+100 \%$ Bio P + 50\% mineral NP, T8: 50\% Bio P + 50\% Bio N + 50\% mineral NP

Pseudostem circumference showed significant higher values at T7, T8 in the first season and T6, T7 and T8 in the second season. These results came in line with Abdel Gawad et al. (2017), who reported that height and circumferences of Grande Naine banana pseudostem increased as consequence of biofertilization and feldspar application.

Data in Table 3 show that, plants treated with $\mathrm{T}_{8}(50 \%$ Bio $\mathrm{P}+50 \%$ Bio $\mathrm{N}+50 \%$ mineral N, P) gave the highest bunch weight in both seasons, while $\mathrm{T}_{2}(100 \%$ Bio $\mathrm{P}$ (P.D.B) $+100 \% \mathrm{~N}$ ) presented the significant lowest value than all tested treatments. In addition, T8 recorded the maximum bunch length and the lowest one registered by T2. These results are in agreement with those reported by Abd El-Naby and Gomaa (2000) and Barakat et al. (2011) who recorded that banana plants supplied with mineral fertilization combined with organic manure improved bunch weight. Also, the results are confirmed by those obtained by Baiea et al. (2015) and Baiea and El-Gioushy (2015) on banana plants.

In both seasons, $\mathrm{T}_{8}(50 \%$ Bio $\mathrm{P}+50 \%$ Bio $\mathrm{N}+50 \%$ mineral $\mathrm{N}, \mathrm{P})$ increased the yield by $2 \%, 4.1 \%$ than the control. Moreover, the rest treatments had intermediate yield among the highest value at T8 $(20,20.4 \mathrm{~T})$ and the lowest one $(14.8,12.4 \mathrm{~T})$ at $\mathrm{T} 2$ $(100 \%$ Bio P (P.D.B $)+100 \% \mathrm{~N})$ treatment during $1^{\text {st }}$ and $2^{\text {nd }}$ seasons, respectively. In this concern, Mai et al. (2005) observed that number of hands/bunch increased with $50 \%$ or $33 \%$ recommended dose of $\mathrm{N}$ plus Azospirillum phosphate solubilizing 
bacteria. Dave et al. (1991), Zake et al. (2000), and Abd el Moniem et al. (2008) found that biofertilization with algal extract significantly improved yield, bunch and hand weight.

Table 3. Effect of Biofertilizers in combination with different levels of $N$, $P$ mineral fertilizers on Bunch weight and length and yield

\begin{tabular}{c|c|c|c|c|c|c}
\hline \multirow{2}{*}{ Treatments } & \multicolumn{2}{|c|}{$\begin{array}{c}\text { Bunch weight } \\
\text { (Kg) }\end{array}$} & \multicolumn{2}{c|}{$\begin{array}{c}\text { Bunch length } \\
\text { (cm) }\end{array}$} & \multicolumn{2}{c}{$\begin{array}{c}\text { Yield } \\
\text { Ton/ } 4200 \mathrm{~m}^{2}\end{array}$} \\
\cline { 2 - 7 } & $\mathbf{2 0 1 6}$ & $\mathbf{2 0 1 7}$ & $\mathbf{2 0 1 6}$ & $\mathbf{2 0 1 7}$ & $\mathbf{2 0 1 6}$ & $\mathbf{2 0 1 7}$ \\
\hline T1 & $24.5 \mathrm{ab}$ & $24.5 \mathrm{abc}$ & $95.75 \mathrm{ab}$ & $97.0 \mathrm{a}$ & $19.6 \mathrm{ab}$ & $19.6 \mathrm{abc}$ \\
T2 & $18.5 \mathrm{~d}$ & $15.5 \mathrm{~d}$ & $81.75 \mathrm{c}$ & $74.75 \mathrm{c}$ & $14.8 \mathrm{~d}$ & $12.4 \mathrm{~d}$ \\
T3 & $21.75 \mathrm{c}$ & $22.5 \mathrm{c}$ & $91.5 \mathrm{abc}$ & $89.25 \mathrm{~b}$ & $17.4 \mathrm{c}$ & $18.0 \mathrm{c}$ \\
T4 & $21.5 \mathrm{c}$ & $22.75 \mathrm{c}$ & $91.25 \mathrm{abc}$ & $87.0 \mathrm{~b}$ & $17.2 \mathrm{c}$ & $18.2 \mathrm{c}$ \\
T5 & $22.25 \mathrm{c}$ & $23.25 \mathrm{bc}$ & $98.0 \mathrm{a}$ & $89.25 \mathrm{~b}$ & $17.8 \mathrm{c}$ & $18.6 \mathrm{bc}$ \\
T6 & $21.25 \mathrm{c}$ & $25.25 \mathrm{ab}$ & $86.0 \mathrm{bc}$ & $96.75 \mathrm{a}$ & $17.0 \mathrm{c}$ & $20.2 \mathrm{ab}$ \\
T7 & $23.0 \mathrm{bc}$ & $25.25 \mathrm{ab}$ & $95.75 \mathrm{ab}$ & $95.5 \mathrm{a}$ & $18.4 \mathrm{bc}$ & $20.2 \mathrm{ab}$ \\
T8 & $25.0 \mathrm{a}$ & $25.5 \mathrm{a}$ & $98.25 \mathrm{a}$ & $98.5 \mathrm{a}$ & $20.0 \mathrm{a}$ & $20.4 \mathrm{a}$ \\
\hline
\end{tabular}

Means within each column followed by the same letter are not significantly different at $\mathrm{P} \leq 0.05$ according to Duncan's multiple range test. T1: Control (100\% mineral NP), T2: $100 \%$ Bio P (P.D.B) $+100 \%$ N, T3: $100 \%$ Bio P $+50 \%$ mineral P $+100 \%$ N, T4: $100 \%$ Bio N (N.F.B) $+100 \%$ mineral P, T5: $100 \%$ Bio N + 50\% mineral N +100\% mineral P, T6: 100\% Bio N +100\% Bio P, T7: $100 \%$ Bio N $+100 \%$ Bio P + 50\% mineral NP, T8: 50\% Bio P + 50\% Bio N + 50\% mineral NP

With respect to fingers No./hand. the differences among the treatments did not reached the limit of significance in the $1^{\text {st }}$ season (Table 4). However, in the $2^{\text {nd }}$ season, $\mathrm{T}_{8}(50 \%$ Bio $\mathrm{P}+50 \%$ Bio $\mathrm{N}+50 \%$ mineral $\mathrm{NP}$ ) resulted in increasing the finger No/hand than T3 and T2, the latter presented the significant lowest value than all treatments.

Table 4. Effect of Biofertilizers in combination with different levels of $N$, $P$ mineral fertilizers on finger characters of Williams Banana fruits

\begin{tabular}{c|c|c|c|c|c|c}
\hline \multirow{2}{*}{ Treatments } & \multicolumn{2}{|c|}{ Finger No./hand } & \multicolumn{2}{c|}{ Finger length(cm) } & \multicolumn{2}{c}{ Finger perimeter(cm) } \\
\cline { 2 - 7 } & $\mathbf{2 0 1 6}$ & $\mathbf{2 0 1 7}$ & $\mathbf{2 0 1 6}$ & $\mathbf{2 0 1 7}$ & $\mathbf{2 0 1 6}$ & $\mathbf{2 0 1 7}$ \\
\hline T1 & $16.75 \mathrm{a}$ & $15.0 \mathrm{ab}$ & $21.3 \mathrm{bc}$ & $21.0 \mathrm{ab}$ & $12.24 \mathrm{a}$ & $11.74 \mathrm{a}$ \\
T2 & $15.25 \mathrm{a}$ & $12.0 \mathrm{c}$ & $20.5 \mathrm{~cd}$ & $19.25 \mathrm{~b}$ & $11.29 \mathrm{bc}$ & $9.5 \mathrm{~b}$ \\
T3 & $16.0 \mathrm{a}$ & $14.5 \mathrm{~b}$ & $21.0 \mathrm{~cd}$ & $21.5 \mathrm{a}$ & $12.24 \mathrm{ab}$ & $12.24 \mathrm{a}$ \\
T4 & $15.75 \mathrm{a}$ & $16.0 \mathrm{ab}$ & $19.63 \mathrm{~d}$ & $20.88 \mathrm{ab}$ & $10.5 \mathrm{c}$ & $11.0 \mathrm{a}$ \\
T5 & $16.5 \mathrm{a}$ & $16.0 \mathrm{ab}$ & $22.0 \mathrm{abc}$ & $21.0 \mathrm{ab}$ & $12 \mathrm{ab}$ & $12.24 \mathrm{a}$ \\
T6 & $16.0 \mathrm{a}$ & $15.75 \mathrm{ab}$ & $21.0 \mathrm{~cd}$ & $21.5 \mathrm{a}$ & $12.0 \mathrm{ab}$ & $12.24 \mathrm{a}$ \\
T7 & $16.50 \mathrm{a}$ & $16.0 \mathrm{ab}$ & $23.0 \mathrm{a}$ & $22.0 \mathrm{a}$ & $12.5 \mathrm{a}$ & $12.24 \mathrm{a}$ \\
T8 & $16.75 \mathrm{a}$ & $16.5 \mathrm{a}$ & $23.3 \mathrm{a}$ & $22.5 \mathrm{a}$ & $12.8 \mathrm{a}$ & $12.4 \mathrm{a}$ \\
\hline
\end{tabular}

Means within each column followed by the same letter are not significantly different at $P \leq 0.05$ according to Duncan's multiple range test. T1: Control (100\% mineral NP), T2: 100\% Bio P (P.D.B) $+100 \%$ N, T3: $100 \%$ Bio P + 50\% mineral P $+100 \%$ N, T4: $100 \%$ Bio N (N.F.B) $+100 \%$ mineral P, T5: 100\% Bio N + 50\% mineral N +100\% mineral P, T6: $100 \%$ Bio N +100\% Bio P, T7: $100 \%$ Bio N $+100 \%$ Bio P + 50\% mineral NP, T8: 50\% Bio P + 50\% Bio N + 50\% mineral NP

The present data revealed that length and perimeter of finger augment as consequence of $\mathrm{T}_{8}(50 \%$ Bio $\mathrm{P}+50 \%$ Bio $\mathrm{N}+50 \%$ mineral $\mathrm{NP})$ and $\mathrm{T}_{7}(100 \%$ Bio $\mathrm{N}$ 
$+100 \%$ Bio $\mathrm{P}+50 \%$ mineral NP) throughout the two growing seasons. on the contrary the lowest value obtained by T4 (100\% Bio N (N.F.B) + $100 \%$ mineral P) and T2 for each of first and second season.

Data in Table 5 revealed that, in both seasons, the highest significant finger weight was obtained by $\mathrm{T} 7$ followed by T8, while T6 recorded the lowest value. The results are in line with El-Shenawi and Hassouna (2004) who found that supplied Williams banana plants with $\mathrm{N}$ at $600 \mathrm{~g}$ ammonium nitrate /plant plus 51 HALEX biofertilizer presented the best finger weight. The highest pulp percentage was recorded at T8 treatment in both seasons.

Table 5. Effect of Biofertilizers in combination with different levels of $N$, $P$ mineral fertilizers on peel weight, pulp weight and pulp \%

\begin{tabular}{c|c|c|c|c|c|c|c|c}
\hline \multirow{2}{*}{ Treatments } & \multicolumn{2}{|c|}{ Finger weight $\mathbf{( g )}$} & \multicolumn{2}{|c|}{ Peel weight $\mathbf{( g )}$} & \multicolumn{2}{c|}{ Pulp weight $(\mathbf{g})$} & \multicolumn{2}{c}{ Pulp (\%) } \\
\cline { 2 - 9 } & $\mathbf{2 0 1 6}$ & $\mathbf{2 0 1 7}$ & $\mathbf{2 0 1 6}$ & $\mathbf{2 0 1 7}$ & $\mathbf{2 0 1 6}$ & $\mathbf{2 0 1 7}$ & $\mathbf{2 0 1 6}$ & $\mathbf{2 0 1 7}$ \\
\hline T1 & $138.3 \mathrm{c}$ & $150.0 \mathrm{~b}$ & $41.8 \mathrm{~b}$ & $57.25 \mathrm{bc}$ & $96.5 \mathrm{c}$ & $92.75 \mathrm{bc}$ & $69.75 \mathrm{ab}$ & $61.83 \mathrm{bc}$ \\
T2 & $115.0 \mathrm{e}$ & $134.5 \mathrm{c}$ & $39.25 \mathrm{~b}$ & $48.10 \mathrm{de}$ & $75.25 \mathrm{e}$ & $86.4 \mathrm{c}$ & $65.43 \mathrm{c}$ & $64.23 \mathrm{~b}$ \\
T3 & $135.5 \mathrm{c}$ & $144.8 \mathrm{~b}$ & $42.75 \mathrm{~b}$ & $53.05 \mathrm{~cd}$ & $92.75 \mathrm{~cd}$ & $91.75 \mathrm{c}$ & $68.45 \mathrm{ab}$ & $63.36 \mathrm{~b}$ \\
T4 & $125.3 \mathrm{~d}$ & $142.8 \mathrm{~b}$ & $40.55 \mathrm{~b}$ & $53.55 \mathrm{c}$ & $84.75 \mathrm{~cd}$ & $89.25 \mathrm{c}$ & $68.0 \mathrm{ab}$ & $62.5 \mathrm{bc}$ \\
T5 & $146.8 \mathrm{~b}$ & $148.0 \mathrm{~b}$ & $44.3 \mathrm{~b}$ & $59.05 \mathrm{ab}$ & $102.50 \mathrm{bc}$ & $88.5 \mathrm{c}$ & $67.3 \mathrm{bc}$ & $59.67 \mathrm{c}$ \\
T6 & $114.8 \mathrm{e}$ & $115.5 \mathrm{~d}$ & $40.56 \mathrm{~b}$ & $45.00 \mathrm{e}$ & $74.25 \mathrm{e}$ & $70.50 \mathrm{~d}$ & $64.67 \mathrm{c}$ & $61.3 \mathrm{bc}$ \\
T7 & $165.5 \mathrm{a}$ & $159.0 \mathrm{a}$ & $53.00 \mathrm{a}$ & $57.07 \mathrm{ab}$ & $112.00 \mathrm{a}$ & $101.30 \mathrm{a}$ & $67.97 \mathrm{ab}$ & $63.71 \mathrm{~b}$ \\
T8 & $160.3 \mathrm{a}$ & $158.0 \mathrm{a}$ & $51.80 \mathrm{a}$ & $63.00 \mathrm{a}$ & $108.00 \mathrm{ab}$ & $95.0 \mathrm{ab}$ & $70.32 \mathrm{a}$ & $70.12 \mathrm{a}$ \\
\hline
\end{tabular}

Means within each column followed by the same letter are not significantly different at $\mathrm{P} \leq 0.05$ according to Duncan's multiple range test. T1: Control (100\% mineral NP), T2: 100\% Bio P (P.D.B) $+100 \%$ N, T3: $100 \%$ Bio P $+50 \%$ mineral P $+100 \%$ N, T4: $100 \%$ Bio N (N.F.B) $+100 \%$ mineral P, T5: $100 \%$ Bio $N+50 \%$ mineral $N+100 \%$ mineral $P, T 6: 100 \%$ Bio $N+100 \%$ Bio $P, T 7: 100 \%$ Bio N $+100 \%$ Bio P + 50\% mineral NP, T8: 50\% Bio P + 50\% Bio N + 50\% mineral NP

Data presented in Table 6 show that, in the $1^{\text {st }}$ season acidity percentage was similar in the fruit of $\mathrm{T} 5(100 \%$ Bio $\mathrm{N}+50 \%$ mineral $\mathrm{N}+100 \%$ mineral P), T6 $(100 \%$ Bio $\mathrm{N}$ $+100 \%$ Bio $\mathrm{P}$ ) beside the control plants, while the lowest acidity percentage obtained by T2 $\left(100 \%\right.$ Bio P (P.D.B) $+100 \%$ N). Moreover, in the $2^{\text {nd }}$ season the highest and the lowest value recorded when plants treated with $\mathrm{T} 5(100 \%$ Bio $\mathrm{N}+50 \%$ mineral $\mathrm{N}$ $+100 \%$ mineral P) and T2 (100\% Bio P (P.D.B) $+100 \%$ N), respectively.

In both seasons the highest fruit TSS as Brix was recorded at T6 $(100 \%$ Bio N $+100 \%$ Bio P) and the lowest value presented with T2 (100\% Bio P (P.D.B) $+100 \%$ N). Considering total sugars content, in the $1^{\text {st }}$ season, T6 $(100 \%$ Bio $\mathrm{N}+100 \%$ Bio P), T7 $(100 \%$ Bio $\mathrm{N}+100 \%$ Bio $\mathrm{P}+50 \%$ mineral NP) and $\mathrm{T} 8(50 \%$ Bio $\mathrm{P}+50 \%$ Bio $\mathrm{N}+$ $50 \%$ mineral NP) gave the highest significant fruit total sugar content, while plants treated with $\mathrm{T} 2(100 \%$ Bio P (P.D.B) $+100 \% \mathrm{~N})$ had the lowest significant value. Moreover, in the second season T7 $(100 \%$ Bio N $+100 \%$ Bio $\mathrm{P}+50 \%$ mineral NP) and T2 $(100 \%$ Bio P (P.D.B) $+100 \% \mathrm{~N})$ had the highest and lowest values, respectively.

Fruit reducing sugar percent was significantly improved in response to T8 (50\% Bio $\mathrm{P}+50 \%$ Bio $\mathrm{N}+50 \%$ mineral NP) in the $1^{\text {st }}$ season as well as, T7 $(100 \%$ Bio $\mathrm{N}+100 \%$ Bio P $+50 \%$ mineral NP) and T8 (50\% Bio P $+50 \%$ Bio $\mathrm{N}+50 \%$ mineral NP) in the $2^{\text {nd }}$ season led to significant reduction in fruit reducing sugar value.

Attia et al. (2009) on banana observed that biofertilization increased TSS and decreased acidity. 
Table 6. Effect of Biofertilizers in combination with different levels of $N$, $P$ mineral fertilizers on finger chemical contents of Williams Banana fruits

\begin{tabular}{c|c|c|c|c|c|c|c|c}
\hline \multirow{2}{*}{ Treatments } & \multicolumn{2}{|c|}{ Acidity (\%) } & \multicolumn{2}{c|}{$\begin{array}{c}\text { TSS } \\
\text { (Brix) }\end{array}$} & \multicolumn{2}{c}{ Total sugar (\%) } & \multicolumn{2}{c}{ Reducing sugar (\%) } \\
\cline { 2 - 9 } & $\mathbf{2 0 1 5}$ & $\mathbf{2 0 1 6}$ & $\mathbf{2 0 1 5}$ & $\mathbf{2 0 1 6}$ & $\mathbf{2 0 1 5}$ & $\mathbf{2 0 1 6}$ & $\mathbf{2 0 1 5}$ & $\mathbf{2 0 1 6}$ \\
\hline T1 & $0.25 \mathrm{a}$ & $0.21 \mathrm{bc}$ & $20.27 \mathrm{bc}$ & $22.12 \mathrm{~cd}$ & $16.49 \mathrm{bc}$ & $17.66 \mathrm{a}$ & $15.00 \mathrm{~b}$ & $15.39 \mathrm{~d}$ \\
T2 & $0.20 \mathrm{c}$ & $0.19 \mathrm{c}$ & $19.37 \mathrm{~d}$ & $19.37 \mathrm{~d}$ & $13.18 \mathrm{e}$ & $13.27 \mathrm{c}$ & $11.16 \mathrm{~d}$ & $11.51 \mathrm{~d}$ \\
T3 & $0.21 \mathrm{bc}$ & $0.22 \mathrm{ab}$ & $24.5 \mathrm{ab}$ & $25.17 \mathrm{ab}$ & $16.04 \mathrm{~cd}$ & $15.82 \mathrm{~b}$ & $14.39 \mathrm{bc}$ & $13.09 \mathrm{c}$ \\
T4 & $0.23 \mathrm{ab}$ & $0.21 \mathrm{bc}$ & $22.5 \mathrm{c}$ & $21.5 \mathrm{~cd}$ & $15.29 \mathrm{~d}$ & $15.52 \mathrm{~b}$ & $13.86 \mathrm{c}$ & $13.65 \mathrm{c}$ \\
T5 & $0.25 \mathrm{a}$ & $0.24 \mathrm{a}$ & $23 \mathrm{bc}$ & $23 \mathrm{bc}$ & $16.33 \mathrm{bcd}$ & $17.94 \mathrm{a}$ & $14.34 \mathrm{bc}$ & $15.57 \mathrm{~b}$ \\
T6 & $0.25 \mathrm{a}$ & $0.20 \mathrm{bc}$ & $25.25 \mathrm{a}$ & $26.75 \mathrm{a}$ & $17.17 \mathrm{a}$ & $17.95 \mathrm{a}$ & $15.09 \mathrm{~b}$ & $16.52 \mathrm{ab}$ \\
T7 & $0.22 \mathrm{bc}$ & $0.22 \mathrm{ab}$ & $23.12 \mathrm{bc}$ & $26.75 \mathrm{a}$ & $17.72 \mathrm{a}$ & $18.72 \mathrm{a}$ & $15.14 \mathrm{~b}$ & $17.36 \mathrm{a}$ \\
T8 & $0.21 \mathrm{bc}$ & $0.22 \mathrm{ab}$ & $24.12 \mathrm{ab}$ & $25.5 \mathrm{ab}$ & $17.92 \mathrm{a}$ & $18.4 \mathrm{a}$ & $16.14 \mathrm{a}$ & $17.26 \mathrm{a}$ \\
\hline
\end{tabular}

Means within each column followed by the same letter are not significantly different at $\mathrm{P} \leq 0.05$ according to Duncan's multiple range test. T1: Control (100\% mineral NP), T2: 100\% Bio P (P.D.B) $+100 \%$ N, T3: $100 \%$ Bio P + 50\% mineral P $+100 \%$ N, T4: $100 \%$ Bio N (N.F.B) $+100 \%$ mineral P, T5: $100 \%$ Bio $\mathrm{N}+50 \%$ mineral $\mathrm{N}+100 \%$ mineral $\mathrm{P}, \mathrm{T} 6: 100 \%$ Bio $\mathrm{N}+100 \%$ Bio $\mathrm{P}, \mathrm{T} 7$ : $100 \%$ Bio $\mathrm{N}$ $+100 \%$ Bio P + 50\% mineral NP, T8: 50\% Bio P + 50\% Bio N + 50\% mineral NP

\section{Leaf chemical composition}

Data in Table 7 show that leaf N, P and $\mathrm{K}$ contents were affected by tested combination of mineral and biofertilizer treatments. In both seasons, T7 (100\% Bio N $+100 \%$ Bio P $+50 \%$ mineral NP) and T8 (50\% Bio P $+50 \%$ Bio N $+50 \%$ mineral NP) showed to be most effective for inducing the greatest values of leaf $\mathrm{N}, \mathrm{P}$ and $\mathrm{K}$. Meanwhile, T2 (100\% Bio P (P.D.B) $+100 \%$ N) for leaf N\%, T5 $(100 \%$ Bio N $+50 \%$ mineral $\mathrm{N}+100 \%$ mineral $\mathrm{P}$ ) for P content and T2 (100\% Bio P (P.D.B) $+100 \% \mathrm{~N}), \mathrm{T} 3$ $(100 \%$ Bio $\mathrm{P}+50 \%$ mineral $\mathrm{P}+100 \% \mathrm{~N})$ for leaf $\mathrm{K} \%$ presented the lowest values for $\mathrm{N}, \mathrm{P}$ and $\mathrm{K}$, respectively in both seasons. Different workers have proposed different critical levels of $\mathrm{N}, \mathrm{P}, \mathrm{K}$ which ranged from 1.8- 4, 0.17- 0.29 and $1.66-6.4 \%$, respectively (Angeles et al., 1993; Memon et al., 2010) and their levels were increased by biofertilizer.

Table 7. Effect of Biofertilizers in combination with different levels of $N$, $P$ mineral fertilizers on chlorophyll $a$ and $b$ content and $N, P$ and $K \%$ content

\begin{tabular}{|c|c|c|c|c|c|c|c|c|c|c|}
\hline \multirow{2}{*}{ Treatments } & \multicolumn{2}{|c|}{$\begin{array}{c}\text { Chlorophyll a } \\
\text { (mg g-1 })\end{array}$} & \multicolumn{2}{|c|}{$\begin{array}{c}\text { Chlorophyll b } \\
\left(\mathrm{mg} \mathrm{g-}^{1}\right)\end{array}$} & \multicolumn{2}{|c|}{$\mathbf{N} \%$} & \multicolumn{2}{|c|}{$\mathbf{P \%}$} & \multicolumn{2}{|c|}{$\mathbf{K} \%$} \\
\hline & 2016 & 2017 & 2016 & 2017 & 2016 & 2017 & 2016 & 2017 & 2016 & 2017 \\
\hline T1 & $2.592 \mathrm{ab}$ & $2.310 \mathrm{de}$ & $1.207 \mathrm{bc}$ & $1.063 \mathrm{c}$ & $2.90 \mathrm{~b}$ & $3.11 \mathrm{~b}$ & $0.23 b$ & $0.24 \mathrm{ab}$ & $2.6 \mathrm{~b}$ & $2.66 \mathrm{~b}$ \\
\hline $\mathbf{T} 2$ & $2.003 \mathrm{c}$ & $2.213 \mathrm{e}$ & $1.015 \mathrm{de}$ & $0.910 \mathrm{~d}$ & $2.72 \mathrm{~d}$ & $2.85 \mathrm{~d}$ & $0.24 \mathrm{ab}$ & $0.24 \mathrm{ab}$ & $2.2 \mathrm{~d}$ & $2.40 \mathrm{~d}$ \\
\hline T3 & $2.162 \mathrm{c}$ & $2.310 \mathrm{de}$ & $0.930 \mathrm{e}$ & $0.952 \mathrm{~cd}$ & 2 & $2.92 \mathrm{c}$ & $0.23 b$ & $0.24 \mathrm{ab}$ & $2.2 \mathrm{~d}$ & $2.40 \mathrm{~d}$ \\
\hline T4 & $2.375 \mathrm{~b}$ & $2.273 \mathrm{e}$ & $1.020 \mathrm{de}$ & $1.035 \mathrm{~cd}$ & $2.79 \mathrm{c}$ & $2.90 \mathrm{~cd}$ & $0.23 b$ & $0.23 \mathrm{ab}$ & $2.46 \mathrm{c}$ & $2.50 \mathrm{c}$ \\
\hline T5 & $2.750 \mathrm{a}$ & $2.615 b c$ & $1.300 \mathrm{ab}$ & $1.255 \mathrm{~b}$ & $2.79 \mathrm{c}$ & $2.92 \mathrm{c}$ & $0.20 \mathrm{c}$ & $0.22 b$ & $2.50 \mathrm{c}$ & $2.60 \mathrm{~b}$ \\
\hline T6 & $2.425 \mathrm{~b}$ & $2.470 \mathrm{~cd}$ & $1.072 \mathrm{cde}$ & $1.330 \mathrm{ab}$ & $2.79 \mathrm{c}$ & $2.92 \mathrm{c}$ & $0.25 \mathrm{ab}$ & $0.25 \mathrm{a}$ & $2.60 \mathrm{~b}$ & $2.62 \mathrm{~b}$ \\
\hline T7 & $2.752 \mathrm{a}$ & $2.815 \mathrm{a}$ & $1.415 \mathrm{a}$ & $1.390 \mathrm{a}$ & $3.25 \mathrm{a}$ & $3.35 \mathrm{a}$ & $0.26 \mathrm{a}$ & $0.25 \mathrm{a}$ & $2.8 \mathrm{a}$ & $2.80 \mathrm{a}$ \\
\hline T8 & $2.500 \mathrm{~b}$ & $2.660 \mathrm{ab}$ & $1.102 \mathrm{~cd}$ & $1.450 \mathrm{a}$ & $3.22 \mathrm{a}$ & $3.32 \mathrm{a}$ & $0.25 \mathrm{ab}$ & $0.25 \mathrm{a}$ & $2.82 \mathrm{a}$ & $2.80 \mathrm{a}$ \\
\hline
\end{tabular}

Means within each column followed by the same letter are not significantly different at $\mathrm{P} \leq 0.05$ according to Duncan's multiple range test. T1: Control (100\% mineral NP), T2: $100 \%$ Bio P (P.D.B) $+100 \%$ N, T3: $100 \%$ Bio P + 50\% mineral P $+100 \%$ N, T4: 100\% Bio N (N.F.B) $+100 \%$ mineral P, T5: $100 \%$ Bio N + 50\% mineral N +100\% mineral P, T6: 100\% Bio N +100\% Bio P, T7: $100 \%$ Bio N $+100 \%$ Bio P + 50\% mineral NP, T8: 50\% Bio P + 50\% Bio N + 50\% mineral NP 
Chlorophyll content showed no clear trend, however, T7 recorded the highest significant content of chlorophyll $\mathrm{a}$ and $\mathrm{b}$ of in both seasons.

\section{Conclusion}

From the obtained results it can be concluded that integrating biofertilizers (Az14 as nitrogen fixation and B6 as phosphate dissolving bacteria) in fertilization program of Williams banana was beneficial in enhancing the most estimated parameters of banana in terms of yield and fruit quality, moreover T7 and T8 treatments are recommended due to their help in minimizing the application of mineral fertilizer to $50 \%$, which is cost-effective and reducing environmental pollution leading to sustainable agriculture production.

\section{REFERENCES}

[1] Abbas, G., Khattak, J. Z. K., Mir, A., Ishaque, M., Hussin, M., Wahedi, H. M., Ahmed, M. S., Ullah, A. (2012): Effect of organic manures with recommended dose of NPK on the performance of wheat (Triticum aestivum L). - Journal of Animal and Plant Sciences 22(3): 683-687.

[2] Abd el Moniem, E. A., Abd-Allah, A. S. E., Ahmed, M. A. (2008): The combined effect of some organic manures, mineral $\mathrm{N}$ fertilizer and Algal cells extract on yield and fruit quality of Williams banana plants. - American-Eurasian. J. Agric. \& Environ. Sci. 4(4): 417-426.

[3] Abd El-Naby, S. K. M., Gomaa, A. M. (2000): Growth, nutritional status, yield and fruit quality of Maghrabi banana as affected by some organic manures and biofertilizers. Minufiya J. Agric. Res. 25(4): 1113-1129.

[4] Abdel Gawad-Nehad, M. A., Amin, O. A., Abd El-Moneim-Eman, A. A., AboSedera, S. A. (2017): Vegetative growth, productivity and fruit quality of grande naine banana plants as influenced by feldspar and bio-fertilization under sandy soil. - Middle East Journal of Agriculture Research 6(2): 294-301.

[5] Akhtar, M. E., Saleem, M. T., Stuffer, M. D. (2003): Potassium in Pakistan Agriculture. Pakistan. Agric. Res. Council. Islamabad, Pakistan.50p.

[6] Angeles, D. E., Summer, M. E., Lahav, E. (1993): Preliminary DRIS norms for banana. Journal of Plant Nutrition 16: 1059-1070.

[7] A.O.A.C. (Association of Official Agricultural Chemists) (1985): Official Methods of Analysis. $-13^{\text {th }}$ Ed. A O.A.C. Int. Virginia, U.S.A.

[8] Attia, M., Ahmed, M. A., Sonbaty, M. R. (2009): Use of biotechnologies to increase growth, productivity and fruit quality of Maghrabi banana under different rats of phosphorous. - World J. Agric. Sci. 5: 211-220.

[9] Baiea, M. H. M., El-Gioushy, S. F. (2015): Effect of some different sources of organic fertilizers in presence of biofertilizer on growth and yield of banana cv. Grand Nine plants. - Middle East Journal of Agriculture 4(4): 745-753.

[10] Baiea, M. H. M., El-Gioushy, S. F., El-Sharony, T. F. (2015): Effect of feldspar and biofertilization on growth, productivity and fruit quality of banana cv. Grand Naine. International Journal of Environment 4(4): 210-218.

[11] Barakat, M. R., El-Kosary, S., Abdl-Nafea, M. H. (2011): Enhancing Williams banana cropping by using some organic fertilization treatments. - J. Hort. Sci. \& Ornamental Plants 3(1): 29-37.

[12] Chapman, H. D., Pratt, P. F. (1961): Methods of analysis for soil, plants and water. Univ. Calif. Div. Agric. Sci. USA. 
[13] Dave, S. K., Kotrodia, J. S., Potel, M. L. (1991): Studies on tissue analysis and nutrient requirement in banana. - J. Hort. 48(4): 305-308.

[14] Dubois, M., Gilles, K. A., Hamilton, J. K., Rebers, P. A., Smith, F. (1956): Colorimetric Method for Determination of Sugars and Related Substances. - Analytical Chemistry 28: 350-356.

[15] Duncan, D. B. (1955): Multiple range and multiple F. Testes. - Biometrics 11: 1-24.

[16] El-Shenawi, M. R., Hassouna, M. B. (2004): Impact of biofertizer on growth and yield of banana Williams in sandy soil at Nubaria region. - J. Agric. Sci. Mansoura Univ. 29(11): 6527-6535.

[17] FAO (2017): FAO STAT. - http://faostat.fao.org/default.aspex.

[18] FAO (2018): FAO STAT 2018. vol. 15. - January, 2018.

[19] Ganapathi, T., Dharmatti, P. R. (2018): Effect of integrated nutrient modules on growth, yield and quality parameters of banana cv. Grand Naine. - Int. J. Curr. Microbiol. App. Sci. 7(1): 1974-1984.

[20] Goldstien, A. H. (1986): Bacterial phosphate solubilization Historical perspective and future prospects. - Am. J. Alt. Agric. 1: 57-65.

[21] Gyaneshwar, P., Naresh, K. G., Parekh, L. J., Poole, P. S. (2002): Role of soil microorganisms in improving P nutrition of plants. - Plant and Soil 245: 83-93.

[22] Hamim, A., Boukeskasse, A., Ouhdouch, Y., Farrouki, A., Barrijal, S., Miche, L., Mrabet, R., Duponnois, R., Hafidi, M. (2019): Phosphate solubilizing and PGR activities of ericaceous shrubs microorganisms isolated from Mediterranean forest soil. Biocatalysis and Agricultural Biotechnology 19: 101128.

[23] Mai, M. A. B., Shamsuddin, Z. H., Zakaria, W., Mahmoud, M. (2005): High yielding and quality banana production through plant growth promoting rhizobacterial (PGPR) inoculation. - Fruits Paris 60: 179-185.

[24] Memon, N., Memon, K. S., Anwar, R., Ahmed, S., Nafees, M. (2010): Status and response to improved NPK fertilization practices in banana. - Pakistan Journal of Botany 42(4): 2369-2381.

[25] Moran, R., Porath, D. (1980): Chlorophyll determination in intact tissues using N, N, dimethylformamide. - Plant Physiol 65: 478-479.

[26] Snedecor, W., Cochran, W. G. (1980): Statistical Methods. - $7^{\text {th }}$ ed. Iowa State Univ. Press Ames. Iowa. U.S.A.

[27] Wilde, S. A., Corey, R. B., Iyer, J. C., Voigt, G. K. (1985): Soil and plant analysis for tree culture. - Oxford and IBH Publishing Company, New Delhi, India. pp. 94-105.

[28] Xu, C., Panis, B., Strosse, H., Li, H., Xiao, H., Fan, H., Swennen, R. (2005): Establishment of embryogenic cell suspensions and plant regeneration of the dessert banana 'Williams' (Musa AAA group). - The Journal of Horticultural Science and Biotechnology 80: 551-556.

[29] Zake, Y. K., Bwamiki, D. P., Nkwiine, C. (2000): Soil management requirement for banana production on the heavy soil around lake Victoria in Uganda. - Acta Hortic. 540: 285-292. 